\title{
The Importance of Cardiovascular Risk in Primary Healthcare
}

\author{
Erika Maria Gonçalves Campana ${ }^{1}$ and Rafael Santos Costa ${ }^{1,2}$ \\ Universidade Iguaçu, ${ }^{\prime}$ Rio de Janeiro, $R J$ - Brazil. \\ Universidade do Estado do Rio de Janeiro, ${ }^{2}$ Rio de Janeiro, RJ - Brazil.
}

Cardiovascular Diseases (CVDs) are the leading cause of death in Brazil and worldwide, determining increased morbidity and disability-adjusted life years. The implementation of health policies, among them, encouraging healthy lifestyle habits and providing access to primary and secondary CVD prevention measures, associated with the treatment of cardiovascular $(\mathrm{CV})$ events are essential to control CVD in all countries, including Brazil. ${ }^{1}$

Arterial hypertension (AH) has a high prevalence in Brazil. It varies according with the population studied and the assessment method used. It is often associated with metabolic disorders, functional and/or structural changes in target organs, being worsened by the presence of other risk factors (RF), such as dyslipidemia, abdominal obesity, glucose intolerance and diabetes mellitus (DM). ${ }^{2}$

For an individualized approach of hypertensive patients, the Ministry of Health proposes the use of risk stratification to define the prognosis and clinical approach to hypertension in primary health care (PHC), including the adoption of the Framingham risk score (FRS). ${ }^{3}$ This score includes the estimate of 10 years of coronary and cerebrovascular events, peripheral arterial disease, or heart failure (HF) and was also the score adopted by the Department of Atherosclerosis of SBC (Departamento de Aterosclerose da Sociedade Brasileira de Cardiologia - SBC-DA). ${ }^{1}$

Published studies have shown that, worldwide, over the past 50 years, the population has increased in weight. This is an important cardiovascular risk and should be

\section{Keywords}

Cardiovascular Diseases/mortality; Cardiovascular Diseases/prevention and control; Risk Factors; Hypertension; Life Style; Obesity; Treatment Adherence. tackled through a government policy in pursuit of an effective action. ${ }^{4}$

A study carried out in Northern Brazil on the prevalence of cardiovascular risk factors in patients with coronary artery disease showed that sedentary lifestyle was present in approximately three quarters of individuals (74.4\%); overweight and obesity in more than half $(64.4 \%)$; and high waist circumference measurements in $88.9 \%$ of women and $51.8 \%$ of men. ${ }^{5}$ In a study conducted in the city of Rio de Janeiro, Pizzi and cols., ${ }^{6}$ evaluated the association between pulse wave velocity (PWV) with some cardiovascular risk factors (blood pressure, serum lipids, insulin and HOMA-IR and adiponectin) in young individuals. The results showed that cardiovascular impairment assessed by PWV was higher among individuals with these risk factors, especially among male subjects and those with higher mean blood pressure. ${ }^{6}$

The study ELSA-Brasil is a multicenter cohort research performed in several Brazilian teaching and research institutions. It was designed to investigate the impact of cardiovascular risk factors (diabetes, history of CVD and its risk factors) on the morbidity, mortality and costs for the Brazilian healthcare system. ${ }^{7}$ In a recent publication of this study, which included data from 8,449 participants aged 35 to 74 years, the authors evaluated the association between abdominal adiposity and the carotid intima-media thickness (CIMT), according to the following indicators: waist circumference (WC), waist-to-hip ratio (WHR), conicity index (C index), lipid accumulation product (LAP) and visceral adiposity index (VAI). It was clear that this association exists in both genders, mainly for waist circumference. ${ }^{8}$ In the multiple logistic regression, the abdominal adiposity diagnosed by WC showed an important effect on the CIMT in both genders (men: OR = 1.47, 95\%CI: 1.22-1.77, women: $\mathrm{OR}=1.38 ; 95 \% \mathrm{CI}: 1.17-1.64)$.

\section{Mailing Address: Erika Campana}

Av. Abílio Augusto Távora, 2134 - Dom Rodrigo, Nova Iguaçu. Postal Code: 26275-580, Nova Iguaçu, Rio de Janeiro, RJ - Brazil.

E-mail: campanaemg@predialnet.com.br, campanaemg@gmail.com 
In the ERICA (Study of Cardiovascular Risk Factors in Adolescents) study, 71,000 adolescents were evaluated in 1,248 schools of 121 Brazilian municipalities. The purpose of the study was to identify cardiovascular risk factors, such as metabolic syndrome, hypertension, physical inactivity, obesity, among others. These data provides a better understanding of issues related to the health of Brazilian adolescents, and allows for more effective public health interventions aimed at protecting this stage of life, since several of these risk factors tend to continue into adulthood. ${ }^{9}$ Among the main study results are: high prevalence of overweight/obesity (25,5\%, 95\%CI: $24.4 \%-26.6 \%)$, high blood pressure $(9.6 \%$, 95\%CI: $8.9 \%-10.3 \%)$ and low HDL-C (47.3\%, 95\%CI: $45.2 \%-49.3 \%)$. The prevalence of metabolic syndrome was of $2.6 \%$ (95\%CI: $2.3 \%-2.9 \%$ ). In addition, more than half of the adolescents reported a sedentary lifestyle. Regional estimates indicated the South region as the one with the highest prevalence of risk factors. The ERICA study also demonstrated an important relationship between the incidence of hypertension and obesity. In fact, the study indicated that obesity, in young

\section{References}

1. Précoma DB, Oliveira GMM, Simão AF, Dutra OP, Coelho OR, Izar MCO, et al. Atualização da Diretriz de Prevenção Cardiovascular da Sociedade Brasileira de Cardiologia - 2019. Arq Bras Cardiol. 2019;113(4):787-891

2. Malachias MVB, Souza WKSB, Plavnik FL, Rodrigues CIS, Brandão AA, Neves MFT, et al., Sociedade Brasileira de Cardiologia. $7^{\mathrm{a}}$ Diretriz Brasileira de Hipertensão Arterial. Arq Bras Cardiol 2016;107(supl 3):1-83.

3. Moreira TR, Toledo LV, Mendonça EJ, Colodette RM, Silva L, Cotta RM - Evaluation of Cardiovascular Risk in Hypertensive Individuals Attending a Primary Health Care Center. Int J Cardiovasc Sci. 2020;33(3):225-226.

4. Jardim PCV. Excesso de peso, o risco cardiovascular do século - Arq Bras Cardiol. 2019;113(2):185-7.

5. Silveira EL, Cunha LM, Pantoja MS, Lima AVM, Cunha NA. Prevalência e distribuição de fatores de risco cardiovascular em portadores de doença arterial coronariana no Norte doBrasil-Rev FacCiênc Méd Sorocaba. 2018;20(3):167-73. populations, could explain one-fifth of the prevalence of hypertension among these adolescents. ${ }^{10}$

In their article published in this issue, Moreira e cols. provide data in agreement with other Brazilian samples. They search to identify the cardiovascular risk factors in hypertensive patients assisted in a primary health care center, located in a municipality of Zona da Mata, State of Minas Gerais, Brazil. The method they used included data collection, administration of questionnaires, anthropometric measurements and laboratory tests. A high cardiovascular risk was associated with male sex, number of medications used and high total cholesterol rates. An inverse correlation was observed between the glomerular filtration rate and cardiovascular risk. They also observed that most risk factors in this population were modifiable. These results show that the data are aligned with the main national and international guidelines, according to which changes in lifestyle and the implementation of public health policies can effectively correct, or at least control, these modifiable cardiovascular risk factors.
6. Pizzi OL, Brandão AA, Pozzan R, Magalhaes MEC, Freitas EV.Velocidade de onda de pulso no jovem . Arq Bras Cardiol. 2013;100(1):60-6

7. Brasil.Ministério da Saúde. ELSA Brasil: maior estudo epidemiológico da América Latina - Rev Saúde Pública. 2009;43(1):1-2.

8. Eickemberg M, Amorim LD, Almeida MC, Aquino EM, Fonseca MJ. e cols. - Indicadores de Adiposidade Abdominal e Espessura MédioIntimal de Carótidas: Resultados do Estudo Longitudinal de Saúde do Adulto - ELSA-Brasil - Arq Bras Cardiol. 2019; 112(3):220-7

9. Cureau FV, Bloch KV, Schaan BD. Estudos dos Riscos Cardiovasculares em Adolescentes (ERICA): resultados e potencialidade - Ver Saúde Pública. 2016; 50 (supl 1):2s.

10. Cureau, Felipe Vogt; Bloch, Kátia Vergetti; Schaan, Beatriz D. Estudo de riscos cardiovasculares em adolescentes (ERICA): resultados principais e perspectivas. Rev Soc Cardiol Estado de Säo Paulo.2019;29(1):28-33. 